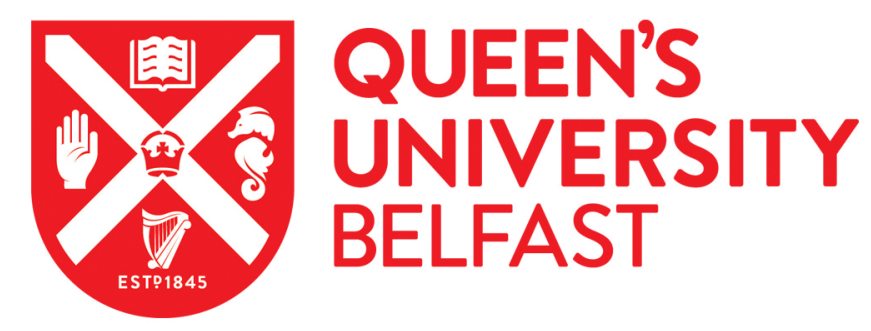

\title{
Effects of EDTA and low molecular weight organic acids on soil solution properties of heavy metal polluted soil
}

Wu, L. H., Luo, Y. M., Christie, P., \& Wong, M. H. (2003). Effects of EDTA and low molecular weight organic acids on soil solution properties of heavy metal polluted soil. Chemosphere, 50, 819-822.

\section{Published in:}

Chemosphere

Queen's University Belfast - Research Portal:

Link to publication record in Queen's University Belfast Research Portal

\section{General rights}

Copyright for the publications made accessible via the Queen's University Belfast Research Portal is retained by the author(s) and / or other copyright owners and it is a condition of accessing these publications that users recognise and abide by the legal requirements associated with these rights.

Take down policy

The Research Portal is Queen's institutional repository that provides access to Queen's research output. Every effort has been made to ensure that content in the Research Portal does not infringe any person's rights, or applicable UK laws. If you discover content in the Research Portal that you believe breaches copyright or violates any law, please contact openaccess@qub.ac.uk. 


\title{
CHEMOSPHERE
}

\section{Effects of EDTA and low molecular weight organic acids on soil solution properties of a heavy metal polluted soil}

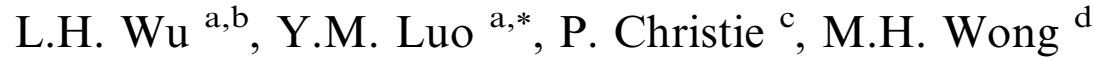 \\ a Institute of Soil Science, Chinese Academy of Sciences, P.O. Box 821, Nanjing 210008, China \\ ${ }^{\mathrm{b}}$ Laboratory of Terrestrial Ecological Processes, Institute of Applied Ecology, Academia Sinica, Shenyang 110016, China \\ ${ }^{\mathrm{c}}$ Department of Agricultural and Environmental Science, Queen's University Belfast, Newforge Lane, Belfast BT9 5PX, UK \\ ${ }^{\mathrm{d}}$ Department of Biology, Hong Kong Baptist University, Kowloon Tong, Hong Kong
}

\begin{abstract}
A pot experiment was conducted to study the effects of EDTA and low molecular weight organic acids (LMWOA) on the $\mathrm{pH}$, total organic carbon (TOC) and heavy metals in the soil solution in the rhizosphere of Brassica juncea grown in a paddy soil contaminated with $\mathrm{Cu}, \mathrm{Zn}, \mathrm{Pb}$ and $\mathrm{Cd}$. The results show that EDTA and LMWOA have no effect on the soil solution $\mathrm{pH}$. EDTA addition significantly increased the TOC concentrations in the soil solution. The TOC concentrations in treatments with EDTA were significantly higher than those in treatments with LMWOA. Adding 3 mmol kg-1 EDTA to the soil markedly increased the total concentrations of $\mathrm{Cu}, \mathrm{Zn}, \mathrm{Pb}$ and $\mathrm{Cd}$ in the soil solution. Compared to EDTA, LMWOA had a very small effect on the metal concentrations. Total concentrations in the soil solution followed the sequence: EDTA $\gg$ citric acid $(\mathrm{CA}) \approx$ oxalic acid $(\mathrm{OA}) \approx$ malic acid $(\mathrm{MA})$ for $\mathrm{Cu}$ and $\mathrm{Pb}$; $\mathrm{EDTA} \gg \mathrm{MA} \gg \mathrm{CA} \approx \mathrm{OA}$ for $\mathrm{Zn}$; and EDTA $\gg \mathrm{MA} \gg \mathrm{CA}>\mathrm{OA}$ for $\mathrm{Cd}$. The labile concentrations of $\mathrm{Cu}, \mathrm{Zn}, \mathrm{Pb}$ and $\mathrm{Cd}$ showed similar trends to the total concentrations.

(c) 2002 Elsevier Science Ltd. All rights reserved.
\end{abstract}

Keywords: EDTA; Low molecular weight organic acids; Soil solution; TOC; Metals

\section{Introduction}

Chelates have been shown to enhance phytoremediation of metals from contaminated soil. EDTA was found by Blaylock et al. (1997) and Wu et al. (1999) to be the most efficient in increasing water-soluble metal concentrations. Exudation of organic compounds by roots may influence ion solubility and uptake through their indirect effects on microbial activity, rhizosphere physical properties and root growth dynamics, and directly through acidification, chelation, precipitation and oxidation-reduction reactions in the rhizosphere (Uren and Reisenauer, 1988; Marschner, 1995). Of these com-

\footnotetext{
${ }^{*}$ Corresponding author. Tel.: +86-25-3228-236; fax: +86-253353-590.

E-mail address: ymluo@mail.issas.ac.cn (Y.M. Luo).
}

pounds, low molecular weight organic acids (LMWOA) are of particular importance due to their metal chelating/ complexing properties for mobilization of mineral nutrients (Marschner et al., 1989; Zhang et al., 1991; Jones et al., 1996) and heavy metals (Mench et al., 1988; Mench and Martin, 1991). Krishnamurti et al. (1997) demonstrated that various LMWOA were able to influence the rate of $\mathrm{Cd}$ release from different soils and increase the solubility of $\mathrm{Cd}$ in bulk soil through the formation of soluble Cd-LMWOA complexes.

The importance of the soil solution as the medium within which contact occurs between the soil reservoir of nutrient ions and heavy metal ions and plant roots has long been recognized. Furthermore, it is thought that metal speciation and ionic activity, rather than the total amount of a dissolved metal, determine plant metal uptake (Kasawneh, 1971). Changes in the dissolved organic carbon (DOC) concentration have a strong impact 
on the solubility of $\mathrm{Cu}$ in soils, with $\mathrm{Cu}$ being more soluble at higher DOC levels (Camobreco et al., 1996).

In this paper we describe a pot experiment in which the dynamics of $\mathrm{pH}$ and of the concentrations of TOC, $\mathrm{Cu}, \mathrm{Zn}, \mathrm{Pb}$ and $\mathrm{Cd}$ in the soil solution during plant growth were studied. Changes in soil solution properties in the rhizosphere of Brassica juncea grown in a $\mathrm{Cu}$-, $\mathrm{Zn}-, \mathrm{Pb}$ - and $\mathrm{Cd}$-contaminated paddy soil due to EDTA and LMWOA addition are also discussed.

\section{Materials and methods}

Plough layer soil $(0-10 \mathrm{~cm})$ was taken from a $\mathrm{Cu}-\mathrm{rich}$ wastewater-irrigated paddy soil from Tai Lake Region, Jiangsu province, east China. The soil was a clay loam paddy soil with a $\mathrm{pH}$ (in water) of 6.3 and had aqua regia-soluble concentrations of $\mathrm{Cu}, \mathrm{Zn}, \mathrm{Pb}$ and $\mathrm{Cd}$ of $116,42.7,6.55$ and $0.19 \mathrm{mg} \mathrm{kg}^{-1}$, respectively.

The pot experiment was conducted using $<2 \mathrm{~mm}$ airdried soil. The treatments were as follows (all amendments added at the rate of $3 \mathrm{mmol} \mathrm{kg}^{-1}$ dry soil): (1) control without EDTA or LMWOA (control); (2) EDTA; (3) oxalic acid (OA); (4) citric acid (CA); and (5) malic acid (MA). Soil (equivalent to $1.5 \mathrm{~kg}$ oven dry basis) was placed in each pot. Basal fertilizers $(0.43$ $\mathrm{g} \mathrm{kg}^{-1} \mathrm{NH}_{4} \mathrm{NO}_{3}$ and $\left.0.33 \mathrm{~g} \mathrm{~kg}^{-1} \mathrm{KH}_{2} \mathrm{PO}_{4}\right)$ were applied. One soil moisture suction sampler (Rhizon SMS: Rhizosphere Research Products, Doderstraat 62, 6706JG Wageningen, The Netherlands) was installed in the centre of each pot to permit sampling of the soil solution. There were three replicates of each treatment in a randomised block design.

Nine seeds of Indian mustard (B. juncea) were sown in each pot and thinned to three seedlings 13 days after sowing. Fifty $\mathrm{mg} \mathrm{kg}^{-1}$ of $\mathrm{Cd}$ as $\mathrm{Cd}\left(\mathrm{NO}_{3}\right)_{2}, 500 \mathrm{mg} \mathrm{kg}^{-1}$ of $\mathrm{Pb}$ as $\mathrm{Pb}\left(\mathrm{NO}_{3}\right)_{2}$ and $500 \mathrm{mg} \mathrm{kg}^{-1}$ of $\mathrm{Zn}$ as $\mathrm{Zn}\left(\mathrm{NO}_{3}\right)_{2}$ were added to each pot as $200 \mathrm{ml}$ of metal salt solution on the 14th, 16th and 19th days after sowing. All pots were adjusted daily to $70 \%$ water holding capacity with distilled water during plant growth. EDTA and LMWOA were added to each pot on the 40th day after sowing. Soil solution samples were collected from the pots at regular intervals. Soil samples were collected from the pots 12 days after EDTA or LMWOA were treated.

Each soil solution sample was separated into several aliquots to allow a range of chemical analyses including $\mathrm{pH}$, total organic carbon (TOC) content, and total $\mathrm{Cu}$, $\mathrm{Zn}, \mathrm{Pb}$ and $\mathrm{Cd}$ concentrations. The heavy metals were separated into labile and non-labile fractions by a resin exchange method. The metals were determined using a TJA inductively coupled plasma atomic emission spectrophotometer. TOC was determined using a Shimadzu 500A TOC Analyzer, and soil solution $\mathrm{pH}$ was mea- sured using a $\mathrm{pH}$ meter. Data were tested statistically by analysis of variance.

\section{Results and discussion}

\subsection{Effects of EDTA on soil solution chemistry}

Fig. 1 shows the $\mathrm{pH}$ and TOC dynamics in the soil solution during growth of Indian mustard. Soil solution $\mathrm{pH}$ decreased by about 0.5 units within the first 10 days. From 10 days to 20 days, the $\mathrm{pH}$ decreased more quickly than during the first 10 days. The phenomenon of $\mathrm{pH}$ decrease was different from the $\mathrm{pH}$ dynamics of Thlaspi caerulescens (Luo et al., 2000), and indicates that rhizosphere acidification could be one of the important mechanisms by which the $B$. juncea plants mobilized soil nutrients and heavy metals. Thereafter, soil solution $\mathrm{pH}$ remained between 5.86 and 6.37 from the 23 th to the 52 th day, and there was no significant effect of EDTA or LOWOA addition on soil solution $\mathrm{pH}$.

The TOC concentration in the soil solution fluctuated within the range $29-120 \mathrm{mgl}^{-1}$. At an industrial polluted site in Europe, the DOC in soil solutions extracted by Rhizon SMS were 37-154 $\mathrm{mgl}^{-1}$ (Knight et al., 1998). EDTA addition significantly increased the TOC concentrations in the soil solution $(P<0.01)$.

The total concentrations of heavy metals in the soil solution are shown in Fig. 2. Six days after $3 \mathrm{mmoll}^{-1}$ of EDTA were added, the $\mathrm{Cu}$ concentration increased from 0.05 to $85.2 \mathrm{mgl}^{-1}$. The EDTA addition also increased soil $\mathrm{Cd}$ solubility, increasing the $\mathrm{Cd}$ concentrations up to $10.5 \mathrm{mgl}^{-1}$. The dynamics of solution $\mathrm{Pb}$ and $\mathrm{Zn}$ were similar to that of $\mathrm{Cd}$.

Fig. 3 shows the dynamics of the labile heavy metal concentrations. Six days after EDTA addition, labile $\mathrm{Cu}$ concentrations increased dramatically from 0.04 up to $0.485 \mathrm{mgl}^{-1}$, and continuously increased to $5.60 \mathrm{mg} \mathrm{l}^{-1}$, but labile $\mathrm{Pb}$ remained at its low level. EDTA addition had little effect on labile $\mathrm{Zn}$ concentrations despite a

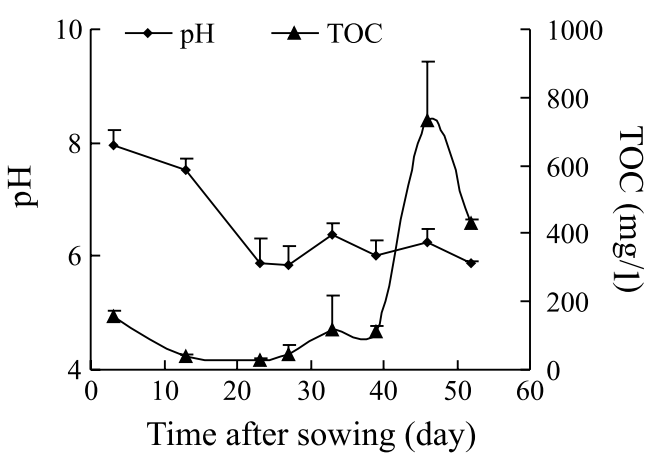

Fig. 1. Soil solution $\mathrm{pH}$ and TOC dynamics in the treatment with EDTA. 


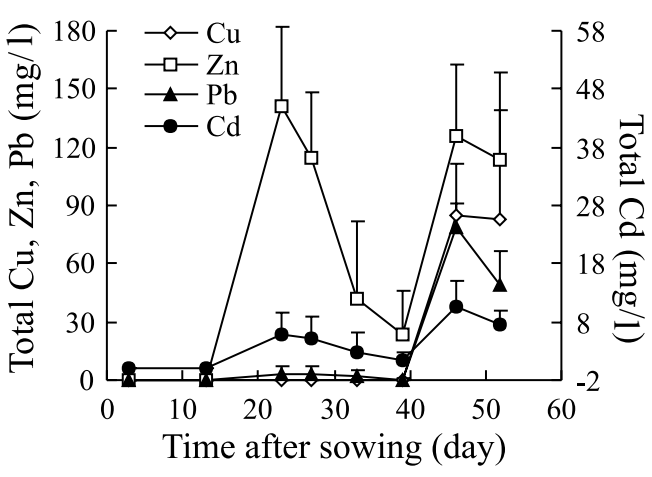

Fig. 2. Soil solution total $\mathrm{Cu}, \mathrm{Zn}, \mathrm{Pb}$ and $\mathrm{Cd}$ dynamics in the treatment with EDTA.

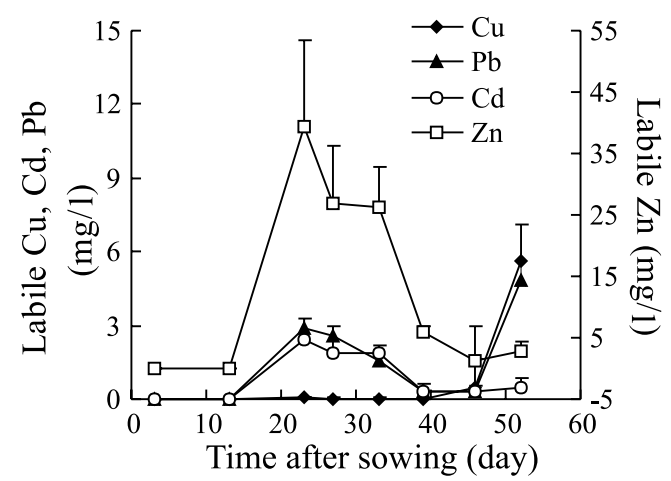

Fig. 3. Soil solution labile $\mathrm{Cu}, \mathrm{Zn}, \mathrm{Pb}$ and $\mathrm{Cd}$ in the treatment of with EDTA.

marked increase in total $\mathrm{Zn}$. Addition of EDTA also had no observable effect on labile $\mathrm{Cd}$ concentrations in the soil solution.

\subsection{Effects of LMWOA on soil solution chemistry}

There was no effect of LMWOA on soil solution $\mathrm{pH}$, but the TOC concentrations in soil solutions in treatment "EDTA" were significantly higher than those of other treatments (Table 1). In the OA treatment, the TOC contents were markedly lower than the control, likely due to microbial decomposition (Table 1).

Table 2 shows the total concentrations of heavy metals in the soil solution. Compared to the control, there was no significant effect on the total heavy metal concentrations in treatment with OA. CA addition also had no effect on $\mathrm{Cu}, \mathrm{Zn}$ or $\mathrm{Pb}$ solubility, but increased soil solution Cd significantly $(P<0.05)$. Adding MA did not affect the $\mathrm{Cu}$ and $\mathrm{Pb}$ concentrations in the soil solution but it significantly increased the solubility of $\mathrm{Zn}$ and $\mathrm{Cd}(P<0.01)$.

Among the EDTA and LMWOA treatments, the concentrations of the metals followed the sequences:
Table 1

Effect of EDTA and LMWOA on soil solution $\mathrm{pH}$ and TOC dynamics

\begin{tabular}{llc}
\hline Treatment & $\mathrm{pH}$ & TOC $\left(\mathrm{mgl}^{-1}\right)$ \\
\hline Control & $5.55 \mathrm{a}$ & $114 \mathrm{~b}$ \\
EDTA & $5.70 \mathrm{a}$ & $356 \mathrm{a}$ \\
OA & $5.94 \mathrm{a}$ & $61 \mathrm{c}$ \\
CA & $5.94 \mathrm{a}$ & $113 \mathrm{~b}$ \\
MA & $5.73 \mathrm{a}$ & $112 \mathrm{~b}$
\end{tabular}

Within each column, means followed by the same letter are not significantly different by least significant difference (LSD) at the $5 \%$ level.

Table 2

Effects of EDTA and LMWOA on the total concentrations of $\mathrm{Cu}, \mathrm{Zn}, \mathrm{Pb}$ and $\mathrm{Cd}$ in the soil solution $\left(\mathrm{mgl}^{-1}\right)$

\begin{tabular}{lcccl}
\hline Treatment & $\mathrm{Cu}$ & $\mathrm{Zn}$ & $\mathrm{Pb}$ & $\mathrm{Cd}$ \\
\hline Control & $0.13 \mathrm{~b}$ & $3.34 \mathrm{c}$ & $0.11 \mathrm{~b}$ & $0.06 \mathrm{~d}$ \\
EDTA & $31.0 \mathrm{a}$ & $90.2 \mathrm{a}$ & $65.8 \mathrm{a}$ & $5.63 \mathrm{a}$ \\
OA & $0.11 \mathrm{~b}$ & $5.76 \mathrm{c}$ & $0.46 \mathrm{~b}$ & $0.19 \mathrm{~d}$ \\
$\mathrm{CA}$ & $0.17 \mathrm{~b}$ & $9.34 \mathrm{c}$ & $1.02 \mathrm{~b}$ & $0.69 \mathrm{c}$ \\
MA & $0.11 \mathrm{~b}$ & $29.9 \mathrm{~b}$ & $2.77 \mathrm{~b}$ & $1.96 \mathrm{~b}$ \\
\hline
\end{tabular}

Within each column, means followed by the same letter are not significantly different by LSD at the $5 \%$ level.

$\mathrm{EDTA} \gg \mathrm{CA} \approx \mathrm{OA} \approx \mathrm{MA}$ for $\mathrm{Cu}$ and $\mathrm{Pb} ; \mathrm{EDTA} \gg$ $\mathrm{MA} \gg \mathrm{CA} \approx \mathrm{OA}$ for $\mathrm{Zn}$; and $\mathrm{EDTA} \gg \mathrm{MA} \gg \mathrm{CA}>$ $\mathrm{OA}$ for $\mathrm{Cd}$. In other words, at the same molar concentrations added to the soil, the metal mobilizing effect of EDTA was higher than that of LMWOA.

The labile concentrations (Table 3) showed similar trends to the total concentrations of $\mathrm{Cu}, \mathrm{Zn}, \mathrm{Pb}$ and $\mathrm{Cd}$. The addition of OA or CA had no significant effect on the changes in labile $\mathrm{Cu}, \mathrm{Zn}, \mathrm{Pb}$ or $\mathrm{Cd}$. MA increased the labile $\mathrm{Zn}$ concentration in the soil solution markedly $(P<0.01)$. EDTA increased the amounts of $\mathrm{Cu}, \mathrm{Zn}, \mathrm{Pb}$ and $\mathrm{Cd}$ in the soil solution, suggesting that most of the metals were probably organically complexed, whereas LMWOA increased mainly labile or free ions.

EDTA and LMWOA can chelate and mobilize the heavy metals in soil, and these two organic acids have been used in decontamination or phytoremediation enhancement of metal polluted soils (Heil et al., 1996; Blaylock et al., 1997; Huang et al., 1997; Wasay et al., 1998). Kedziorek et al. (1998) found in the early days that $\mathrm{Pb}$ and $\mathrm{Cd}$ were readily solved and translocated by EDTA. The potential environmental risk must be recognized at the early stages of EDTA and LMWOA application. The metals of labile complexes could be absorbed and taken up directly by plants. If some methods could be found to decompose these organometal complexes in the short term, then the proportion of free ions would increase. In the meantime, metal uptake by plants would also be enhanced, thus minimizing the environmental risk. 
Table 3

Effects of EDTA and LMWOA on the labile concentrations of $\mathrm{Cu}, \mathrm{Zn}, \mathrm{Pb}$ and $\mathrm{Cd}$ in the soil solution

\begin{tabular}{|c|c|c|c|c|c|c|c|c|}
\hline \multirow[t]{2}{*}{ Treatment } & \multicolumn{2}{|l|}{$\mathrm{Cu}$} & \multicolumn{2}{|l|}{$\mathrm{Zn}$} & \multicolumn{2}{|l|}{$\mathrm{Pb}$} & \multicolumn{2}{|l|}{$\mathrm{Cd}$} \\
\hline & $\mathrm{mg}^{-1}$ & $\%$ Total $\mathrm{Cu}$ & $m g 1^{-1}$ & $\%$ Total $\mathrm{Zn}$ & $\mathrm{mg}^{-1}$ & $\%$ Total $\mathrm{Pb}$ & $\mathrm{mg}^{-1}$ & $\%$ Total Cd \\
\hline Control & $0.01 \mathrm{~b}$ & 5.3 & $0.6 \mathrm{~b}$ & 18.5 & $0.06 \mathrm{~b}$ & 50.9 & 0.02 & 32.8 \\
\hline EDTA & $2.59 \mathrm{a}$ & 8.4 & $14.0 \mathrm{a}$ & 15.5 & $3.82 \mathrm{a}$ & 5.8 & 0.67 & 12.0 \\
\hline $\mathrm{OA}$ & $0.05 \mathrm{~b}$ & 46.4 & $2.8 \mathrm{~b}$ & 49.5 & $0.38 \mathrm{~b}$ & 82.0 & 0.08 & 43.4 \\
\hline CA & $0.09 \mathrm{~b}$ & 52.7 & $3.0 \mathrm{~b}$ & 32.0 & $0.98 \mathrm{~b}$ & 95.9 & 0.25 & 36.9 \\
\hline MA & $0.05 \mathrm{~b}$ & 42.9 & $12.8 \mathrm{a}$ & 42.8 & $1.19 \mathrm{~b}$ & 43.0 & 0.91 & 46.5 \\
\hline
\end{tabular}

Within each column, means followed by the same letter are not significantly different by LSD at the $5 \%$ level.

\section{Acknowledgements}

We are grateful for grant-aided support from the Natural Science Foundation of China (nos. 49831070 and 49871042), the Major State Basic Research and Development Program of the People's Republic of China (G1999011807). We are also grateful to the Postdoctoral Science Foundation of China, the Open Laboratory of Terrestrial Ecological Processes and the Joint Open Laboratory of Soil and Environment (JOLSE), at the Institute of Soil Science, Chinese Academy of Sciences for their financial support.

\section{References}

Blaylock, M.J., Salt, D.E., Dushenkov, S., Zakharova, O., Gussman, C., Kapulnik, Y., Ensley, B.D., Raskin, I., 1997. Enhanced accumulation of $\mathrm{Pb}$ in Indian mustard by soilapplied chelating agents. Environ. Sci. Technol. 31 (3), 860 865 .

Camobreco, V.J., Richards, B.K., Steenhuis, T.S., Peverly, J.H., McBride, M.B., 1996. Movement of heavy metals through undisturbed and homogenized soil columns. Soil Sci. 161 (11), 740-750.

Heil, D., Hanson, A., Samani, Z., 1996. The competitive binding of lead by EDTA in soils and implications for heap leaching remediation. Radioact. Waste Manage. Environ. Restor. 20 (2-3), 111-127.

Huang, J.W., Chen, J.J., Berti, W.R., Cunningham, S.D., 1997. Phytoremediation of lead-contaminated soils: role of synthetic chelating in lead phytoextraction. Environ. Sci. Technol. 31 (3), 800-805.

Jones, D.L., Darrah, P.R., Kochain, L.V., 1996. Critical evaluation of organic acid mediated iron dissolution in the rhizosphere and its potential role in root iron uptake. Plant Soil 180 (1), 57-66.

Kasawneh, F.E., 1971. Solution ion activity and plant growth. Soil Sci. Soc. Am. Proc. 35, 426-436.
Kedziorek, M.A.M., Dupuy, A., Bourg, A.C.M., Compère, F., 1998. Leaching of $\mathrm{Cd}$ and $\mathrm{Pb}$ from a polluted soil during the percolation of EDTA: laboratory column experiments modeled with a non-equilibrium solubilization step. Environ. Sci. Technol. 32 (11), 1609-1614.

Knight, B.P., Chaudri, A.M., McGrath, S.P., Giller, K.E., 1998. Determination of chemical availability of cadmium and zinc in soils using inert moisture samplers. Environ. Pollut. 99 (3), 293-298.

Krishnamurti, G.S.R., Huang, P.M., Van Rees, K.C.J., 1997. Kinetics of cadmium release from soils as influenced by organic: implications in cadmium availability. J. Environ. Qual. 26 (1), 271-277.

Luo, Y.M., Christie, P., Baker, A.J.M., 2000. Soil solution Zn and $\mathrm{pH}$ dynamics in non-rhizosphere soil and in the rhizosphere of Thlaspi caerulescens grown in a $\mathrm{Zn} / \mathrm{Cd}$ contaminated soil. Chemosphere 41 (1-2), 161-164.

Marschner, H., Treeby, M., Romheld, V., 1989. Role of rootinduced changes in the rhizosphere for iron acquisition in higher plants. Z. Pflanzenernahr. Bodenk. 152 (3), 197-204.

Marschner, H., 1995. Mineral Nutrition of Higher Plants, second ed. Academic Press, San Diego, CA, USA.

Mench, M., Martin, E., 1991. Mobilization of cadmium and other metals from two soils by root exudates of Zea mays L., Nicotiana tabacum L., and Nicotiana rustica L. Plant Soil 132 (2), 187-196.

Mench, M., Morel, J.L., Guckert, A., Gruillet, B., 1988. Metal binding with root exudates of low molecular weight. J. Soil Sci. 39 (4), 521-527.

Uren, N.C., Reisenauer, H.M., 1988. The role of root exudates in nutrient acquisition. Adv. Plant Nutr. 3, 79-114.

Wasay, S.A., Barringto, S.F., Tokunaga, S., 1998. Remediation of soils polluted by heavy metals using salts of organic acids and chelating agents. Environ. Technol. 19 (4), 369-380.

Wu, J., Hsu, F.C., Cunningham, S.D., 1999. Chelate-assisted $\mathrm{Pb}$ phytoextraction: $\mathrm{Pb}$ availability, uptake, and translocation constraints. Environ. Sci. Technol. 33 (11), 1898-1904.

Zhang, F., Romheld, V., Marschner, H., 1991. Release of zinc mobilizing root exudates in different plant species as affected by zinc nutritional status. J. Plant Nutr. 14 (7), 675-686. 